\title{
PECULIARITIES OF DIFFERENT TYPES OF THE ACCOMMODATIVE ESOTROPIA AND PUPILLO-ACCOMMODATIVE SYSTEM IN CHILDREN
}

\author{
Bushuyeva N. N., Martynuyk S. V., Senyakina A. S. \\ Odessa, Ukraine
}

\begin{abstract}
Objective - the study of visual dysfunctions, ACPS in children with the most common types of AE.
Materials and Methods: A complex ophthalmological examination (visometry, binoculometry, refractometry, accommodometry, strabometry, the study of convergence, pupillography) in 88 patients aged from 6 to 18 with refractive $\mathrm{AE}$ (45 children), nonrefractive $\mathrm{AE}$ ( 31 patients) and the combinated $\mathrm{AE}$ (12 patients).

Results. Besides the already known differences in the state of refraction and the value of index AC/A, the abovementioned types of $\mathrm{AE}$ differ from each other in such functions as visual acuity, fusion power, binocular vision, convergence. Using pupillography it was found that in patients with any kind of AE both eyes' pupils were narrowed in comparison with healthy children, their reaction to light was weakened considerably. The latent periods of the pupillary light reflex and the pupillary near reflex were increased more than three times compared with healthy children. The latent periods of pupillary dilatation after light stimulation and after convergence weakening were also increased. The authors believe that such disturbances of the pupillary reactions indicate reduction of the lability, increase ACPS inactivity that indicate the functional changes in the brainstem structures of the patients with AE.
\end{abstract}

УдК 617.713-001.5-089.84

\section{ПОРІВНЯЛЬНИЙ АНАЛІЗ ЕФЕКТИВНОСТІ РІЗНИХ СПОСОБІВ ПЕРВИННОЇ ХІРУРГІЧНОЇ ОБРОБКИ ПРОНИКАЮЧИХ ПОРАНЕНЬ РОГІВКИ}

\author{
Н. Ф. Боброва, д. М. Н., проф., В. І. Шевчик, аспірант, М. П. Кульбіда, м. н. С.
}

Державна установа «Інститут очних хвороб і тканинної терапії ім. В. П. Філатова

Академії медичних наук України»

\begin{abstract}
Нами проведен сравнительный анализ ПХО проникающих ранений роговищы с использованием сквозных и несквозных роговичных швов. Изучена динамика изменений остроты зрения, развитие индуцированного астигматизма, сроки пребывания больных в стационаре, изменение площади рубиа, а также коэффициента качества формирования рубца роговицы (который определялся как соотношение длины рубца кего площади) в сроки от 3 дней до одного года после ПХО. Выявлено статистически достоверное преимущество сквозных роговичных швов с различной длиной и шагом шва перед традиционным способом с ушиванием на 2/3 глубины роговицы и одинаковыми швами по размерам и шагом шва.
\end{abstract}

Ключові слова: проникаючі поранення ока, ПХО рогівки, наскрізні шви рогівки

Ключевые слова: проникающие ранения глаза, ПХО роговицы, сквозные швы роговицы

АКТУАЛЬНІСТЬ. Проникаючі поранення рогівки складають від 52 до $70 \%$ серед усіх пошкоджень органа зору. В Україні серед травм ока, що призводять до інвалідності, проникаючі поранення займають лідируюче положення, становлячи $24,1 \%$, а серед працездатного населення - 30,1\%, що зумовлює високу медико - соціальну значимість даної патології (Аніна Є. І., Мартопляс К. В., 2008).

Одним із основних факторів, що впливають на функціональний результат, є якість проведення первинної хірургічної обробки (ПХО) травмованого ока. Метою первинної хірургічної обробки ран рогівки є усунення рани рогівки з відновленням iï цілісності та створення умов для загоєння первинним натягом. Підвищення точності відновлення усіх анатомічних співвідношень трав- мованої рогівки з формуванням найбільш тонкого рубця та зменшенням післяопераційного астигматизму, а також профілактика розвитку зрощень з райдужкою $є$ першочерговими завданнями первинної хірургічної обробки проникаючих поранень рогівки.

Мета роботи. Виявити оптимальний спосіб проведення ПХО ран рогівки шляхом порівняльного аналізу ефективності різних способів первинної хірургічної обробки проникаючих поранень рогівки.

МАТЕРІАЛ ТА МЕТОДИ ДОСЛІДЖЕННЯ. Об'єм клінічних досліджень становили 87 хворих (87 очей) з лінійними проникаючими пораненнями рогівки різної до-

(C) Н. Ф. Боброва, В. І. Шевчик, М. П. Кульбіда, 2011 
вжини та форми. В залежності від способу первинної хірургічної обробки проникаючого рогівкового поранення виділені основна та контрольна група хворих.

Основна група включала 43 хворих 3 проникаючим пораненням рогівки, котрим проводилась ПХО за запропонованим нами способом (Патент України № 46474 від 25.03.2009). Суть способу полягає в проведенні вузлових наскрізних довгих, сильно затягнутих швів на периферії рогівки та коротких, мінімально затягнутих швів в центральній зоні. Проведення швів починають від периферії до центру, намагаючись залишити оптичну зону рогівки без швів. Крок між ними становить половину довжини попереднього шва.

В контрольній групі було 44 хворих, яким проводилась ПХО за загальноприйнятим способом, що полягає в ушиванні рани рогівки вузлуватими швами на $2 / 3$ її товщини, відступаючи на 1 мм від кожного краю рани та 1,5-2 мм один від одного (Р. А. Гундорова, 2009).

3 метою ідентифікації клінічного матеріалу сформовано практично однорідні групи хворих за віком, статтю, довжиною рани рогівки, гостротою зору та часом до госпіталізації (таблиця 1).

Таблиця 1

Порівняння основної та контрольної груп за вихідними показниками

\begin{tabular}{|c|c|c|c|c|c|}
\hline \multirow{3}{*}{ Показник } & \multicolumn{4}{|c|}{ Група хворих } & \multirow{3}{*}{$\begin{array}{c}\text { Тест } \\
\text { Манна-Уітні } \\
\mathbf{p}^{*}\end{array}$} \\
\hline & \multicolumn{2}{|r|}{ основна } & \multicolumn{2}{|r|}{ контрольна } & \\
\hline & $\mathbf{M} \pm \sigma$ & $\begin{array}{c}\text { Медіана (нижня й верхня } \\
\text { квартилі) }\end{array}$ & $\mathbf{M} \pm \sigma$ & $\begin{array}{c}\text { Медіана (нижня й верхня } \\
\text { квартилі) }\end{array}$ & \\
\hline $\begin{array}{c}\text { Час від травмування до } \\
\text { допомоги, година }\end{array}$ & $44,7 \pm 9,1$ & $15(4 ; 72)$ & $47,2 \pm 14,7$ & $5(3 ; 51)$ & 0,23 \\
\hline Довжина рани, мм & $\begin{array}{c}8,42 \pm 5,49 \\
\mathrm{n}=43\end{array}$ & $7,03(4,19 ; 13,10)$ & $\begin{array}{c}9,70 \pm 5,30 \\
n=44\end{array}$ & $9,24(4,90 ; 13,83)$ & 0,32 \\
\hline $\begin{array}{c}\text { Гострота зору при } \\
\text { надходженні }\end{array}$ & $\begin{array}{c}0,20 \pm 0,04 \\
\mathrm{n}=26\end{array}$ & $0,10(0,02 ; 0,30)$ & $\begin{array}{c}0,29 \pm 0,05 \\
\mathrm{n}=17\end{array}$ & $0,10(0,04 ; 0,40)$ & 0,42 \\
\hline Вік хворих, роки & $33,5 \pm 25,2$ & $\begin{array}{c}25 \\
(10 ; 55)\end{array}$ & $32,7 \pm 18,9$ & $\begin{array}{c}32 \\
(17 ; 46)\end{array}$ & 0,88 \\
\hline
\end{tabular}

*-двобічна оцінка

До основної групи входили $36(83,7 \%)$ чоловіків та $7(16,3 \%)$ жінок, в контрольну 40 (90,1 \%) чоловіків та 4 (9,9\%) жінки. Дітей в основній групі було 16, в контрольній - 13. Аналіз комплексної перевірки усіх показників за критерієм Фішера не виявив статистично значимої різниці між пацієнтами основної та контрольної груп, що свідчить при можливість достовірно порівнювати результати різних способів ПХО. Клінічно білышість хворих мали радіально направлені проникаючі рани рогівки 3 середньою довжиною рани $(8,42 \pm 5,49)$ мм для хворих 3 основної групи та $(9,70 \pm 5,30)$ мм 3 контрольної. Як бачимо, довжина рани у хворих з проникаючим пораненням рогівки при використанні наскрізних швів дещо менша ніж у хворих при ПХО ненаскрізними швами, але розбіжність між групами статистично не значима. Ізольована травма лише рогівки відмічалась в 3 хворих основної групи та у 4 в контрольній. Найбільш частим було поєднання проникаючого поранення рогівки 3 пошкодженням райдужки (у 36 хворих прооперованих за запропонованим способом та у 39 з використанням загальноприйнятого способу ПХО). Також пошкодження кришталика на момент надходження було виявлено у 5 хворих 3 основної групи та у 4 з контрольної.

При обстеженні хворих використовувались наступні методики i апаратура: візометрія, кераторефрактометрія на апараті RK 600 «Reichert», біомікроскопія 3 допомогою щільових ламп XCEL 400 фірми «Reichert», офтальмоскопія електроофтальмоскопом Mini 2000 фірми «Неine» та 3 використанням лінзи 90Д «OCULAR», ехобіометрія за допомогою AXIS -II PR «Quantel medical» та рентгенографія орбіт в двох проекціях.

Обстеження хворих проводилось щоденно, для статистичного аналізу використовувались дані, отримані в перший, третій, тридцятий день та через рік після травми. Перебіг формування рубця рогівки оцінювали по наступним критеріям: площа рубця та коефіцієнт якості сформованого рубця рогівки, що визначався як відношення довжини рубця до його площі; розвиток посттравматичного астигматизму; наявність чи відсутність зрощень райдужки з рубщем рогівки; підвищення гостроти зору; тривалість перебування в стаціонарі.

Довжина та площа рубця рогівки оцінювались по даним комп'ютерної графіки, яка формувалась з електронних фотографій рогівок, занесених до бази даних [1]. 3 методів статистичної обробки ми використали критерій ШапіроУілка для перевірки вибіркових розподілів на відповідність нормальному закону розподілу [5]. Для визначення розбіжностей в середніх тенденціях двох непов'язаних вибірок непараметричний критерій Манна-Уітні (ВілкоксонаМанна-Уітні) U. Для визначення розбіжностей в середніх тенденціях двох пов'язаних вибірок користувалися парним критерієм Вілкоксона.

РЕЗУЛЬТАТИ ДОСЛІДЖЕНЬ ТА ЇХ ОБГОВО-

РЕННЯ. У хворих основної групи в перший післяопераційний день явища змішаної ін'єкції судин кон'юнктиви виявлено у 21343 пацієнтів. Відмічалось помутніння строми рогівки в ділянці рани, яке незначно перевищувало розмір самої рани. Адаптація країв рани рогівки у всіх випадках була задовільною (проба Зейделя негативна). Формування передніх синехій ні в одному випадку виявлено не було. Стан прозорості рогівки дозволяв оглянути подальші відділи ока в усіх пацієнтів.

У 42 з 44 хворих контрольної групи в перший післяопераційний день відмічалось посилення кон'юнктивальної ін'єкції судин ока. Характерною ознакою була наявність дифузного набряку рогівки, 
більш вираженого в ділянці ушитої рани, що захоплював площу рогівки приблизно втричі більшу за розміри самої рани. Проба Зейделя у всіх випадках була негативна.

Очі пацієнтів основної групи на третій післяопераційний день були вже майже спокійними. Помутніння рогівки відмічалось лише в зоні проведення швів, десцеметит та передні синехії не відмічались ні в одному випадку. Фільтрації вологи передньої камери як з рани, так і по ходу швів не спостерігалось. Визначення коефіцієнту якості формування посттравматичного рубця рогівки показало, що він складав від 0,03 до 0,11. Це втричі перебільшувало значення коефіцієнта при проведенні ПХО традиційним способом, що свідчило про формування більш ніжного рубця при використанні швів на всю глибину рогівки. Середнє значення індукованого астигматизму склало $(2,0 \pm 0,7)$ дптр. У 4 хворих з основної групи відбувалось прогресування набухання кришталикових мас, в зв'язку з чим на третій день після ПХО їм була виконана факоемульсифікація посттравматичної катаракти 3 імплантацією штучного кришталика. Розходження країв рани під час проведення оперативного втручання не було. Стан прозорості рогівки дозволив провести операцію без ускладнень.

У хворих контрольної групи на третій післяопераційний день набряк рогівки залишався незмінним у 39 хворих і лише у 5 незначно зменшився. В 6 пацієнтів відмічалось формування передніх синехій, що привело до повторного хірургічного втручання - передньої синехіотомії. Оперативне втручання виконано на третій день після ПХО. Коефіцієнт якості формування посттравматичного рубця рогівки становив від 0,01 до 0,04. Середнє значення індукованого астигматизму склало $(4,4 \pm 1,2)$ дптр.

Через місяць після травми для хворих основної групи характерною була наявність ніжного рубця рогівки, передніх синехій виявлено не було. Всім хворим проведено зняття наскрізних рогівкових швів. Краї рани адаптовані добре, підтікання вологи передньої камери в місці проведених швів не виявлено. Коефіцієнт якості формування посттравматичного рубця рогівки складав від 0,053 до 0,126 . Рівень індукованого астигматизму склав $(1,2 \pm 0,3)$ дптр.

У хворих контрольної групи відмічалось формування білісуватого, непрозорого рубця рогівки з наявністю набряку оточуючих тканин у всіх пацієнтів. В 5 хворих виявлена поверхнева васкуляризація рубця, що починалась переважно з ділянки лімбу, найближче розташованої до краю рани. В 9 випадках (20,5 \%) наявна передня синехія, спаяна 3 рубцем рогівки. Коефіцієнт якості формування посттравматичного рубця рогівки покращився в порівнянні з коефіцієнтом на 3 день і становив від 0,014 до 0,056, проте залишався більше ніж втричі меншим за коефіцієнт у хворих, прооперованих за розробленим способом з застосуванням наскрізних швів. Рани рогівки, ушиті за загальноприйнятим способом, через місяць після ПХО приводили до розвитку астигматизму в $(2,8 \pm 0,7)$ дптр.

Через рік після травми у 39 пацієнтів з основної групи сформувався ніжний напівпрозорий рубець рогівки, що по розмірам та формі нагадував форму отриманої рани. Коефіцієнт якості формування посттравматичного рубця рогівки складав від 0,087 до 0,211. Рівень астигматизму перебував в межах фізіологічного астигматизму - $(0,8 \pm 0,2)$ дптр.

У 6 пацієнтів контрольної групи відмічено формування субтотального більма рогівки. Формування рубця рогівки, що займає площу подібну до розмірів рани, виявлено лише у 7 пацієнтів. Коефіцієнт якості формування посттравматичного рубця становив від 0,019 до 0,071 (табл. 2). Рівень астигматизму у хворих контрольної групи зменшився, але залишався більшим в порівнянні з хворими основної групи - $(2,3 \pm 0,6)$ дптр проти $(0,8 \pm 0,2)$ дптр.

Зміни коефіцієнту якості формування посттравматичного рубця наведено в таблиці 2.

Таблиця 2

Показники коефіцієнту якості сформованого рубця в залежності від способу ПХО проникаючого поранення рогівки в різні терміни після операції.

\begin{tabular}{|l|c|c|c|}
\hline \multirow{2}{*}{$\begin{array}{c}\text { Термін після } \\
\text { ПХО }\end{array}$} & \multicolumn{2}{|c|}{$\begin{array}{c}\text { Коефіцієнт якості формування } \\
\text { рубця рогівки }\end{array}$} & $\begin{array}{c}\text { Тест } \\
\text { Манна-Уітні }\end{array}$ \\
\cline { 2 - 4 } & $\begin{array}{c}\text { Основна } \\
\text { група }\end{array}$ & $\begin{array}{c}\text { Контрольна } \\
\text { група }\end{array}$ & p* \\
\hline На 3 день & $0,062 \pm 0,019$ & $0,022 \pm 0,008$ & $<0,00001$ \\
\hline $\begin{array}{l}\text { Чере3 1 } \\
\text { місяць }\end{array}$ & $0,099 \pm 0,029$ & $0,032 \pm 0,014$ & $<0,00001$ \\
\hline Чере3 1 рік & $0,149 \pm 0,039$ & $0,044 \pm 0,016$ & $<0,00001$ \\
\hline
\end{tabular}

Як видно з таблиці 2, в усі періоди спостереження коефіцієнт якості сформованого рубця рогівки у хворих основної групи більше ніж втричі перевищував цей коефіцієнт в контрольній группі. Це свідчить про формування меншого по площі рубця рогівки при використанні наскрізних швів незалежно від довжини рогівкової рани. Зміни коефіцієнту якості сформованого рубця в кожній групі є високо достовірними $\left(\chi^{2}<0,00001\right)$, також статистично достовірною є різниця між групами в усі періоди спостереження $(\mathrm{p}<0,00001)$.

Ступінь індукованого рогівкового астигматизму в залежності від способу ПХО в різні терміни після операції наведено в таблиці 3.

Як видно з вищенаведеної таблиці, ступінь індукованого астигматизму в усі терміни спостереження у хворих основної групи був меншим в порівнянні з контрольною і через рік після ПХО склав 0,8 $\pm 0,2$ та 2,3 $\pm 0,6$ відповідно $(\mathrm{p}<0,0001)$.

Тривалість стаціонарного лікування у хворих основної та контрольної груп відображена в таблиці 4. 
Таблиця 3

Показники індукованого астигматизму в залежності від способу ПХО проникаючого поранення рогівки в різні терміни після операції

\begin{tabular}{|l|c|c|c|}
\hline \multirow{2}{*}{ Термін після ПХО } & \multicolumn{2}{|c|}{$\begin{array}{c}\text { Індукований астигма- } \\
\text { тизм, дптр }\end{array}$} & $\begin{array}{c}\text { Тест } \\
\text { Манна-Уітні }\end{array}$ \\
\cline { 2 - 4 } & $\begin{array}{c}\text { Основна } \\
\text { група }\end{array}$ & $\begin{array}{c}\text { Контрольна } \\
\text { група }\end{array}$ & $\mathbf{p}^{*}$ \\
\hline На 3 день & $2,0 \pm 0,7$ & $4,4 \pm 1,2$ & $<0,0001$ \\
\hline Через 1 місяць & $1,2 \pm 0,3$ & $2,8 \pm 0,7$ & $<0,0001$ \\
\hline Чере3 1 рік & $0,8 \pm 0,2$ & $2,3 \pm 0,6$ & $<0,0001$ \\
\hline
\end{tabular}

Таблиця 4

Тривалість стаціонарного лікування у хворих основної та контрольної груп.

\begin{tabular}{|c|c|c|c|c|c|}
\hline \multirow{4}{*}{$\begin{array}{l}\text { Трива- } \\
\text { лість } \\
\text { перебу- } \\
\text { вання в } \\
\text { стаці- } \\
\text { онарі, } \\
\text { день }\end{array}$} & \multicolumn{4}{|c|}{ Групи хворих } & \multirow{2}{*}{$\begin{array}{c}\text { Тест } \\
\text { Манна- } \\
\text { Уітні }\end{array}$} \\
\hline & \multicolumn{2}{|c|}{ основна } & \multicolumn{2}{|c|}{ контрольна } & \\
\hline & $\mathbf{M} \pm \sigma$ & $\begin{array}{c}\text { Медіана } \\
\text { (нижня } \\
\text { й верхня } \\
\text { квартилі) }\end{array}$ & $\mathbf{M} \pm \sigma$ & $\begin{array}{c}\text { Медіана } \\
\text { (нижня } \\
\text { й верхня } \\
\text { квартилі) }\end{array}$ & $\mathbf{p}^{*}$ \\
\hline & $5,8 \pm 2,9$ & $5(4 ; 8)$ & $8,5 \pm 4,3$ & $8(5 ; 11)$ & 0,0025 \\
\hline
\end{tabular}

*-двобічна оцінка

3 наведених даних видно, що при використанні ПХО проникаючих поранень рогівки в основній групі середня тривалість перебування хворих в стаціонарі була на 2,7 днів менша в порівнянні з хворими контрольної групи (p=0,0025).

Гострота зору хворих основної та контрольної груп до та після операції наведена в таблиці 5.

Таблиця 5

Відновлення гостроти зору у хворих основної та контрольної груп.

\begin{tabular}{|c|c|c|c|}
\hline \multirow{3}{*}{ Гострота зору } & \multicolumn{2}{|c|}{ Групи хворих } & \multirow{2}{*}{$\begin{array}{c}\text { Тест } \\
\text { Манна- } \\
\text { Уітні }\end{array}$} \\
\hline & основна & контрольна & \\
\hline & $\mathbf{M} \pm \sigma$ & $\mathbf{M} \pm \sigma$ & $\mathbf{p}^{*}$ \\
\hline До операції & $0,20 \pm 0,04$ & $0,29 \pm 0,05$ & 0,42 \\
\hline Після операції & $0,42 \pm 0,18$ & $0,33 \pm 0,12$ & 0,02 \\
\hline Тест Вілкоксона, p & $<0,0002$ & $<0,03$ & \\
\hline
\end{tabular}

*-двобічна оцінка

Як ми бачимо з таблиці 5, при надходженні гострота зору в пацієнтів основної групи склала $0,20 \pm 0,09$, а в контрольній 0,29 $\pm 0,03(\mathrm{p}=0,42)$, при виписці - в основній группі $0,42 \pm 0,18$ та контрольній $-0,33 \pm 0,12(\mathrm{p}=0,02)$. Покращення гостроти зору є статистично значимим окремо в основній та контрольній групах, але для пацієнтів основної групи він є сильнішим (тест Вілкоксона $-\mathrm{p}<0,0002$ та $\mathrm{p}<0,03$ відповідно).

Використовувати рогівкові шви при ПХО ран рогівки запропонував Diffenbach ще в 1847 році.
Проте їх використання залишалось казуїстичним до 50 років минулого століття. Після появи більш тонкого шовного матеріалу використання рогівкових швів стало єдино вірним рішенням при ПХО проникаючих поранень рогівки. За результатами експериментальних досліджень Dannington 1951, Barraquer, 1964, В. В. Войно-Ясенецького, 19793 використанням шовкових 3/0- 6/0 рогівкових швів встановлено, що найкращий результат дає проведення швів на 1/2-2/3 глибини рогівки. Проведення швів при ПХО на всю товщину рогівки викликає iii некроз, васкуляризацію та фіброз. Також автори показали, що при використанні наскрізних швів $€$ висока імовірність занесення інфекції та проростання епітелію в передню камеру ока як по ходу раньового каналу, так і по самому шву. Але були і інші думки - так Б. Л. Поляк, 1950 на великій серії дослідів (більше 500 кролів) довів повну безпеку проведення наскрізних швів з шовку 6/00. Ні в одному з випадків не було виявлено інфікування чи вростання епітелію через канали шва в передню камеру, також не було витікання вологи передньої камери через ці канали. Навпаки, у всіх випадках формування грубого рубця рогівки, зрощеного з підлеглими тканинами, на серійних патологоанатомічних зрізах було встановлено, що це відбувалося тоді, коли десцеметова оболонка не попадала в шов і краї рани в задньому відділі залишались не з'єднаними.

Розробка загальноприйнятого на даний час способу ПХО грунтується на дослідженнях з використанням швів на 2/3 глибини рогівки (Гундорова Р. А., 1986, 2009). 3 удосконаленням операційного інструментарію, появою атравматичних голок, використанням іншого, більш тонкого шовного матеріалу - нейлону - замість шовку, були виконані нові експериментальні роботи, що показали перевагу проведення наскрізних швів перед ненаскрізними (Chiapella A., Rosenthal A., 1985, Forlini C., 2007, Kuhn F., 2008). 360 років минулого століття в офтальмохірургії починають використовувати нейлон замість шовку. Запропонований W.Huges в 1939 році він набув широкого застосування завдяки працям R.Troutman (1963). На відміну від шовку нейлон добре переноситься всіма тканинами ока. За даними А. М. Добромислова, Л. В. Нисневич, 1983, Buratto L., Iori M., 1996 сучасні еластичні нитки (нейлон 10/00) настільки тонкі, що тиск, які вони створюють на прошиті тканини, не здатний викликати їх некроз. До того ж нейлон не є гігроскопічним, тому не проводить вологу з передньої камери назовні та інфекцію в око по ходу нитки.

В результаті проведеного нами дослідження по використанню наскрізних швів за розробленим способом встановлена їх безпечність та значна перевага перед загальноприйнятим способом. 


\section{ВИСНОВКИ}

1. Використання наскрізних рогівкових швів при ПХО проникаючих поранень рогівки в усіх випадках дозволило уникнути розвитку такого ускладнення, як зрощення райдужки з рубцем рогівки, що відмічались у 20,5 \% хворих при ПХО за загальноприйнятим способом.

2. Ступінь індукованого шовного астигматизму при використанні запропонованого способу ПХО проникаючих поранень рогівки був значно меншим в усі періоди спостереження і через рік після травми склав $(0,8 \pm 0,2)$ дптр проти $(2,3 \pm 0,6)$ дптр при застосуванні загальноприйнятого способу ( $<<0,0001)$.

3. Коефіцієнт якості сформованого рубця рогівки, що визначається як співвідношення довжини рани до площі сформованого рубця, через рік після ПХО був втричі більшим при використанні наскрізних швів рогівки в порівнянні з не наскрізними швами $(0,149 \pm 0,039$ та $0,044 \pm 0,016$ відповідно), що свідчить про формування більш ніжного та меншого по площі рубця рогівки $(\mathrm{p}<0,00001)$.

4. Запропонований спосіб ПХО дозволив отримати значне підвищення гостроти зору у хворих з проникаючими пораненнями рогівки (з $0,20 \pm 0,04$ до $0,42 \pm 0,18$ проти $0,29 \pm 0,05$ до 0,33 $\pm 0,12$ при застосуванні загальноприйнятого способу, $\mathrm{p}=$ $0,0025)$.

5. При застосуванні наскрізних рогівкових швів скоротився час перебування хворого в стаціонарі в середньому на 2,7 дня в порівнянні з загальноприйнятою методикою $(\mathrm{p}=0,0025)$.

\section{ЛІТЕРАТУРА}

1. Боброва Н. Ф. Кількісна оцінка особливостей формування посттравматичного рубця рогівки внаслідок проникаючих поранень рогівки / Н. Ф. Боброва, В. І. Шевчик // Офтальмол. журн. - 2010. - № 3. C. $46-50$.

2. Боброва Н. Ф. Спосіб первинної хірургічної обробки проникаючих поранень рогівки / Н. Ф. Боброва, В. І. Шевчик // Офтальмол. журн. - 2010. - № 4. C.65-68.

3. Гублер Е. В. Вычислительные методы анализа и распознавания патологических процессов / Л., «Медицина», 1978. - $296 \mathrm{c.}$

4. Гундорова Р. А. Травмы глаза : [монография] / Р. А. Гундорова, В. В. Нероева, В. В. Кашникова. - М.: «ГЭОТАР - Медиа», 2009. - С. 34-65.

5. Кобзарь А. И. Прикладная математическая статистика. Для инженеров и научных работников. - М.: ФИЗМАТЛИТ, 2006. - 816 с. Стр. 277-278.

6. Пат. 46474 Україна, МПК (2009) А61В 1/00. Спосіб хірургічного лікування лінійних проникаючих поранень рогівки / Боброва Надія Федорівна, Шевчик Василь Іванович; заявник і власник Боброва Надія Федорівна, Шевчик Василь Іванович. - № u 200906487; заявл. 22.06.09; опубл. 25.12.09, Бюл.№ 24.

7. Тюрин Ю. Н. Непараметрические методы статистики / М., «Знание», 1978. - 63 с.

8. Kuhn F. Ocular traumatology / F. Kuhn // Springer-Verleg, Berlin Heidelberg, 2008. - 538 p.

9. Rowsey J. J. Refractive reconstruction for acute eye injuries / J. J. Rowsey, J. C. Hays // Ophthalmic Surg. 1984. - Vol. 15. - P. 565-574.

Поступила 11.05.2011 Рецензент д-р мед наук Н. А. Чуднявцева

\title{
COMPARATIVE ANALYSIS OF EFFICACY OF DIFFERENT METHODS OF PRIMARY SURGICAL TREATMENT OF THE PENETRATING CORNEAL INJURIES
}

\author{
Bobrova N. F., Shevchik V. I., Kulbida M. P. \\ Odessa, Ukraine
}

There was carried out the comparative analysis of PST of the penetrating corneal injuries with the use of through and blind corneal sutures. There were studied the dynamics of changes in visual acuity, the development of the induced astigmatism, the periods of patients' hospital stay, a change in the area of the scar as well as the quality coefficient of the scar formation of the cornea (which was defined as the relationship of the scar length to its area) from 3 days to one year after PST. The statistically reliable advantage of the through corneal sutures with different length and step of the suture over the traditional method with taking in $2 / 3$ depths of the cornea and identical sutures similar in size and step of the suture is revealed. 